\title{
Sodium Measurement
}

National Cancer Institute

\section{Source}

National Cancer Institute. Sodium Measurement. NCI Thesaurus. Code C64809.

A quantitative measurement of the amount of sodium present in a sample. 